\title{
Emerging themes in idiopathic intracranial hypertension
}

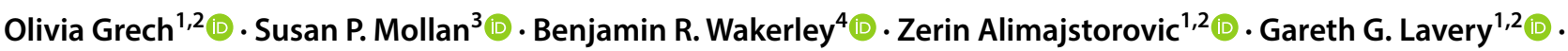 \\ Alexandra J. Sinclair ${ }^{1,2,5}$
}

Received: 18 May 2020 / Revised: 14 July 2020 / Accepted: 15 July 2020 / Published online: 22 July 2020

(c) The Author(s) 2020

\begin{abstract}
Purpose Idiopathic intracranial hypertension (IIH) is a rare disorder characterised by raised intracranial pressure. The underlying pathophysiology is mostly unknown and effective treatment is an unmet clinical need in this disease. This review evaluates key emerging themes regarding disease characteristics, mechanisms contributing to raised intracranial pressure and advances in potential therapeutic targets.

Findings IIH is becoming more common, with the incidence rising in parallel with the global obesity epidemic. Current medical management remains centred around weight management, which is challenging. Metabolic investigations of patients have identified specific androgen profiles in cerebrospinal fluid (CSF), which suggest an endocrine dysfunction impacting

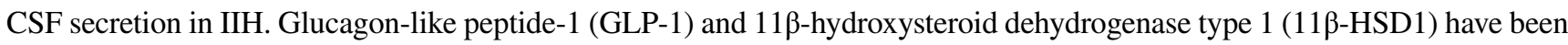
found to play a role in CSF dynamics in IIH and have formed the basis of the first clinical trials looking at new treatments. Conclusions Identification of novel molecular targets thought to underlie IIH pathology is now being translated to clinical trials.
\end{abstract}

Keywords Glucagon-like peptide-1 (GLP-1) - Intracranial pressure · Idiopathic intracranial hypertension · Headache · Obesity · Papilloedema

\section{Background}

Idiopathic intracranial hypertension (IIH), also known as pseudotumor cerebri, is a rare disorder of unknown cause characterised by raised intracranial pressure (ICP) in the absence of underlying structural pathology. IIH typically affects women of reproductive age, with a significant association with obesity and recent weight gain $[1,2]$. Although IIH is considered a rare syndrome, the incidence is increasing [3], and appears to reflect country specific rates of obesity [4].

The majority of patients with IIH present with headache, visual disturbance (e.g. loss of peripheral vision, transient visual obscurations, horizontal double vision) and pulsatile tinnitus. Some patients also experience back pain, dizziness and cognitive disturbances $[1,5,6]$. Papilloedema (swelling of the optic nerve head) is a hallmark feature of IIH and left

1 Metabolic Neurology, Institute of Metabolism and Systems Research, College of Medical and Dental Sciences, University of Birmingham, Birmingham B15 2TT, UK

2 Centre for Endocrinology, Diabetes and Metabolism, Birmingham Health Partners, Birmingham B15 2TH, UK

3 Birmingham Neuro-Ophthalmology, Ophthalmology Department, Queen Elizabeth Hospital, University Hospitals Birmingham NHS Foundation Trust, Birmingham B15 2TH, UK

4 Department of Neurology, Gloucestershire Royal Hospital, Gloucester, UK

5 Department of Neurology, Queen Elizabeth Hospital, University Hospitals Birmingham NHS Foundation Trust, Birmingham B15 2TH, UK 
untreated could lead to optic atrophy and permanent visual loss [7]. Rarely, patients present with papilloedema in the absence of any other symptoms. Preserving the vision is a key priority in the management of IIH. Commonly, patients with IIH develop chronic headaches, which significantly reduce quality of life and are typically difficult to treat $[8,9]$.

In 2018, the first consensus guidelines for the investigation and management of IIH in adults was established [2]. It outlines diagnostic principles and key management strategies, namely to treat underlying disease accomplished by weight loss, preserve vision via emergency surgery (when required) and minimise headache morbidity.

The exact pathology underlying IIH remains unknown. Improved treatment options are an unmet clinical need in this disease area [10]. Recent mechanistic studies have identified therapeutic targets such as glucagon-like peptide-1 (GLP-1) [11] and 11 -hydroxysteroid dehydrogenase type 1 (11 $\beta$-HSD1), which have formed the basis of IIH randomised clinical trials [12-14]. The aim of this review is to inform the reader of emerging issues and present new key highlights in the therapeutic development for IIH.

\section{Epidemiology}

IIH is considered a rare condition. Previously, the incidence within the general population was believed to be between 0.5 and 2 per 100,000 [15-19]. Recent evaluations in the UK, including the largest cohort study to date, reported a $108 \%$ increase from 2.26 to 4.69 per 100,000 between 2002 and 2016 [3]. Another large case controlled cohort study found the incidence of IIH in females had tripled from 2.5 to 9.3 per 100,000 between 2005 and 2017 [20]. Secondary to the rising incidence of IIH is the health care cost of the disorder: annual hospital costs in England rose from $£ 9.2$ million to $£ 49.9$ millon between 2002 and 2014 and was predicted to rise to $£ 462.7$ million by 2030 [3]. In 2007 in the US, IIH patients had exceptionally high admission rates of $38 \%$ of all those coded with IIH for that year, with costs exceeding $\$ 444$ million. This estimate also included lost work income [21]. Repeat hospital admissions may reflect that IIH is a disease of social deprivation [20], but also highlights the ineffectiveness of IIH treatment for decades.

Obesity (>90\%), female sex and reproductive age are significant risk factors associated with IIH [1]. An epidemiology study in the US found that women have an eight times likelihood of the disorder compared to men, [17] which is significantly increased when overweight and of reproductive age (20-44 years) with an incidence of $12-20$ per 100,000 [15-17]. Paediatric studies of IIH are not well established; however, one UK study found an incidence of 0.71 per 100,000 , which was found to increase with age. For children aged $12-15$ years, there is also an association with obesity, whereas the pathophysiology in younger patients remains unclear [22]. IIH in males is uncommon; however, of note males are more likely to develop severe visual loss [23].

\section{Working towards understanding the mechanisms of raised ICP}

The James Lind Alliance research priority setting partnership gave voice to patients and medical professionals to outline the most important topics regarding IIH. Identifying the underlying biological mechanisms was recognised as the most important topic [10]. Whilst it is thought that IIH is a multifactorial disorder, altered CSF dynamics is a final common pathway [6]. The choroid plexus (ChP) is the primary site of CSF production and secretion. It is composed of specialised epithelial cells which utilise the $\mathrm{Na}^{+} / \mathrm{K}^{+}$-ATPase ion pump to move $\mathrm{Na}^{+}$across the apical membrane and create an osmotic gradient to regulate CSF movement [24, 25]. Targeting receptors and channels implicated in CSF production including aquaporins, transient receptor potential vanilloid type 4 (TRPV4), sodium potassium cotransporter (NKCCl) and GLUT1 poses potential treatments for CSF disorders [26]. It should be noted that CSF plays a role in protein and metabolite clearance in the CNS; therefore, modulating its production and movement may potentially have deleterious effects. There are several hypotheses, which all relate to disturbances of this CSF equilibrium.

\section{Glucagon-like peptide-1}

Glucagon-like peptide-1 (GLP-1) is a gut peptide secreted in response to food by the distal small intestine and stimulates glucose-dependent insulin secretion [27]. It is also synthesised by neurons in the nucleus tractus solitarius and is involved in satiety and weight loss [28]. In the distal proximal tubule, it interacts with GLP-1 receptors (GLP-1R) to stimulate cAMP-dependent pKA pathways, which result in prevention of $\mathrm{Na}^{+}$absorption into the bloodstream [29]. The ChP also express GLP-1R and interaction with its agonist exendin- 4 , was demonstrated to reduce $\mathrm{Na}^{+} / \mathrm{K}^{+}$ATPase, a surrogate measurement of CSF secretion [11]. Single subcutaneous administration of exendin- 4 in rat models of raised ICP were able to successfully lower ICP for $24 \mathrm{~h}$, demonstrating the efficacy of this potential drug [11]. GLP-1R agonists are already licensed for the use in diabetes and obesity. The IIH Pressure Trial, ISRCTN12678718, is a randomised controlled trial assessing the effect of repurposing this drug in patients with raised ICP and the results from this trial should be released soon [14]. 


\section{Androgen excess}

The predominant risk factors for $\mathrm{IIH}$, including female sex, obesity and reproductive age, suggest a contribution of sex hormones in the pathophysiology of raised ICP. The prevalence of polycystic ovarian syndrome (PCOS) has been found higher in studies of IIH patients than the general population and the phenotypes of both disorders; namely female sex and obesity, are similar [30]. Androgen excess have been associated with $\mathrm{IIH}$, with increased circulating levels of androgens associated with earlier onset in women [31], and female-to-male transgender patients developing IIH after commencing testosterone therapy [32]. Using liquid chromatography-tandem mass spectrometry (LCMS), it has been possible to define a metabolome signature in the serum and CSF of IIH patients, which features excess androgens but is distinct from obesity and PCOS [33]. Until recently, the role of excess testosterone in IIH pathology was unknown. Treatment of rat $\mathrm{ChP}$ tissue with testosterone exhibited a marked increase in $\mathrm{Na}^{+} / \mathrm{K}^{+}$ATPase activity, a surrogate measurement of CSF secretion. This in combination with the finding of androgen receptors on the human $\mathrm{ChP}$, provides evidence for the role of androgen excess in increased CSF secretion [33].

\section{$11 \beta$-Hydroxysteroid dehydrogenase type 1}

The enzyme $11 \beta$-hydroxysteroid dehydrogenase type $1(11 \beta$ HSD1) has a key role in regulating CSF secretion by converting cortisone to its active form cortisol, which amplifies glucocorticoid signalling pathways and facilitates the transport of $\mathrm{Na}^{+}$ions. It is expressed and active in the $\mathrm{ChP}$ and has demonstrated a role in IIH pathology [34]. 11 $\beta$-HSD1 offers a link between obesity and raised ICP, as global activity was found to be reduced following therapeutic weight loss in IIH patients, which also correlated with a reduction in ICP [35]. The enzyme has been previously found to be dysregulated in obesity [36], with high levels found in human fat [37] and overexpression mouse models resulting in visceral obesity and a metabolic disorder [38]. Phenotyping studies have begun to elucidate a metabolically distinct profile of adipose tissue of IIH patients. LCMS-based 11 $\beta$-HSD1 assays in the adipose tissue of IIH patients demonstrated an increased generation of cortisol when treated with cortisone, despite no differences in 11 $\beta$-HSD1 gene expression [39].

Selective inhibitors of $11 \beta$-HSD1 have been used to treat obesity, a metabolic syndrome and diabetes mellitus type 2 [40]; therefore, the potential for these to reduce ICP has also been hypothesised. Recently a double-blind randomized controlled trial in the UK was able to demonstrate that AZD4017, a 11 $\beta$-HSD1 inhibitor reduced ICP in IIH patients which was correlated to a reduction in serum cortisol:cortisone ratio [12]. This was the first phase II randomized trial of any medicine in IIH and confirmed the safety and tolerability of this $11 \beta$-HSD1 inhibitor.

\section{Cytokines and adipokines}

Obesity is a chronic inflammatory condition, in which adipose tissue is capable of functioning as an endocrine organ, secreting a number of pro-inflammatory factors including cytokines, adipokines and chemokines [41]. As cytokine expression profiles are significantly different in IIH patients, could these factors have a role in IIH? [42]. Studies utilising miRNA/mRNA analysis have highlighted abnormalities in pro-inflammatory pathways in the CSF and serum of patients with raised ICP [43]. In particular, compared to controls, chemokine (C-C motif)-ligand 2 (CCL2) has been found to be significantly higher in the CSF of IIH patients, [42] whilst others found IL-2 and IL-17 to be significantly elevated [44]. These suggest a possible inflammatory pathway in IIH pathology and more work is underway to determine the significance of these findings, independent of the metabolic effects of obesity [42]. In one such experiment in the lab, one group of female rats was fed a high fat diet and another group were exposed to IIH-associated inflammatory factors. Both groups of animals exhibited increased CSF secretion with reduced CSF drainage when treated with CCL2 [45]. These studies further highlight a pathogenic link between weight gain and raised ICP. Could this pathway be targeted for a biomarker of altered CSF drainage, or as a therapy?

\section{Current medical management in IIH}

Weight loss is an effective management strategy to induce IIH remission (Fig. 1). The Birmingham weight loss prospective trial [46] demonstrated that a very low-calorie diet $(1777 \mathrm{~kJ} /$ day $(425 \mathrm{kcal} /$ day $))$ resulted in significant weight loss $(15.3 \pm 7.0 \%$ of body weight), significantly lowered ICP and led to a significant improvement in papilloedema, vision and headache outcomes. There are a number of case series detailing alternative methods of weight loss in IIH [47]. The results of one multicentre, randomised controlled trial designed to assess if weight loss through bariatric surgery is a more effective sustainable treatment for IIH than lifestyle modification through a community weight management program is currently awaited [48]. The IIH consensus guidelines recommend weight loss for all those who have typical IIH [2].

Acetazolamide is a carbonic anhydrase inhibitor widely used to lower ICP and is a first-line treatment in IIH. Although the exact mechanism of action of acetazolamide on CSF dynamics remains unknown, cell models have demonstrated that it inhibits $\mathrm{Na}^{+} / \mathrm{K}^{+}$ATPase in the ChP [49, 

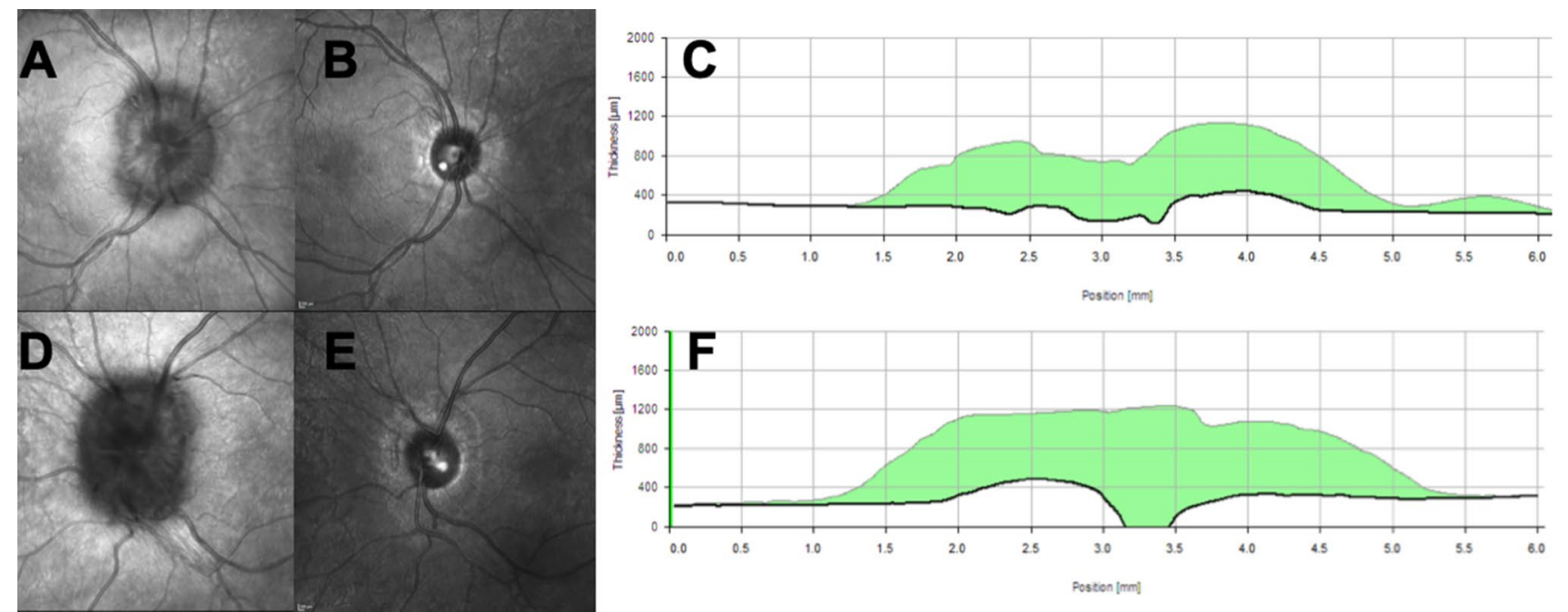

Fig. 1 Optical coherence tomography (OCT) images from a young Caucasian woman who presented with papilloedema. CT head and CT venogram showed no abnormalities. CSF opening pressure was $52 \mathrm{~cm}$ CSF, with normal contents. Her weight was $99 \mathrm{~kg}$ and body mass index $40.2 \mathrm{~kg} / \mathrm{m}^{2}$. Following lifestyle intervention of a caloriecontrolled diet and exercise alone, she lost $15 \mathrm{~kg}$ (BMI 34.1) putting her disease into complete remission within 8 weeks. a Infrared image

50]. The IIH treatment trial (IIHTT) was a multicentre randomised, double-blind study, which investigated the use of acetazolamide in conjunction with a low sodium diet in IIH patients with mild visual loss and reported modest improvement in the perimetric mean deviation of the visual field [51]. In clinical practice, acetazolamide is poorly tolerated by many patients $[51,52]$, and more recently the clinical benefit of acetazolamide has been questioned [53]. One preclinical study reported that acetazolamide had no effect on ICP in female rats and that topiramate in comparison was far superior at reducing ICP [54]. Topiramate is also a carbonic anhydrase inhibitor and has the additional benefits of inducing weight loss in some patients and being an effective migraine preventative [55]. Although Topiramate has been reported to relieve symptoms in IIH [56, 57], further controlled trials with it are required to see whether it is truly effective in treating this condition.

\section{Headache in IIH}

\section{Clinical features}

There are few clinical studies characterising IIH headache [9]. Previously, IIH headaches were considered "high pressure" and, therefore, aggravated by Valsalva manoeuvre, worse when supine and often present on waking or causing the patient to wake from sleep $[9,58]$. However, more recent studies indicate that the majority of headaches in IIH of the right optic nerve; $\mathbf{b}$ infrared image of the right optic nerve following weight loss; $\mathbf{c}$ shows the central cross section, and the amount of reduction in the retinal nerve fibre layer in the right eye over the 8 weeks. d Infrared image of the left optic nerve; e infrared image of the left optic nerve following weight loss; f shows the central cross section and the amount of reduction in the retinal nerve fibre layer in the left eye over the 8 weeks

meet the International Headache Society criteria for either episodic migraine, chronic migraine or tension-type headache $[51,59,60]$. In the IIHTT, $84 \%$ of participants had headache at baseline [60]. Headache is a chronic disabler in $\mathrm{IIH}$ and significantly reduces quality of life [8]. The relationship between ICP and headache in IIH remains complicated. Although reduction in ICP was found to alleviate headache in weight loss studies [46], severity, frequency and disability of headache did not correlate with lumbar puncture opening pressure at baseline in the IIHTT [60].

\section{Management}

The phenotype of IIH headache appears to mirror that of episodic and chronic migraine [9] and increasingly off-label migraine treatment is used in IIH patients to treat headache without any formal evidence of efficacy [2]. Overuse of simple analgesics, opiates, and non-steroidal anti-inflammatory drugs is common in IIH and may result in medicationoveruse headache $[61,62]$. Patients who achieve 10-15\% weight loss often see an improvement in their headache [46], although sometimes this can only be achieved with bariatric surgery [63]. Although therapeutic LP may reduce headache in the short term, repeated LPs are not recommended as they may result in complications such as intracranial hypotension $[64,65]$. Headache generation and pain are thought to be due to peripheral sensitisation of the trigeminovascular system, in which innervation of the dura by nociceptive trigeminal fibers, leads to release of vasoactive neuropeptides including 
calcitonin gene-related peptide (CGRP) and substance $\mathrm{P}$ [66-68]. In the case of migraine, repeated periods of sensitisation over time is thought to cause a decrease in nociceptive threshold and may result in chronicity [69]. CGRP is thought to play an important role in the pathogenesis of migraine. Plasma CGRP is elevated during migraine attacks and administration of exogenous CGRP may induce migraine without aura in sufferers. Recent trials also demonstrate that monoclonal antibodies against CGRP or the CGRP receptor are effective for the treatment of chronic and episodic migraine [59, 70-75]. Evidence of CGRP involvement in post-traumatic headache, $[76,77]$ which also features raised ICP, suggests that these therapeutics would also be effective for IIH headache. Furthermore, the headache phenotype in IIH is typically migraine [60]. At present, there is no trial evidence for the use of CGRP monoclonal antibodies to treat headaches with a migrainous phenotype in IIH.

\section{Vision in IIH}

\section{Clinical features}

Visual symptoms of raised intracranial pressure may include: visual blurring, transient visual obscurations (TVOs) and double vision [7]. Often patients can have a mild hyperopic shift due to papilloedema causing visual blurring. TVOs, where there is a short-lived greying or blacking out of the vision in either or both eyes, with return to normal vision, is more common in the acute setting of raised ICP. These often happen on bending or during a Valsalva manoeuvre. Where they increase in frequency at rest is a red flag of progression to fulminant disease requiring urgent assessment. If horizontal binocular diplopia is reported, then a full extra ocular movement examination will likely reveal a unilateral or bilateral sixth-nerve palsy [7]. Rarely other cranial nerve palsies have been reported in IIH [2]. If monocular diplopia is reported, a close examination of the macula with fundoscopy and OCT may reveal either fluid in the acute setting or an epiretinal membrane in the chronic setting.

\section{Examination}

On examination papilloedema (unilateral or bilateral disc swelling) is one of the essential features required to diagnose IIH [78]. However, examination of the fundus can be challenging [58], and up to $40 \%$ of those sent to a tertiary centre had an incorrect diagnosis of IIH made due to diagnostic error in the fundal examination [79]. If there is any clinical uncertainty, papilloedema should be confirmed by an experienced specialist, [2] as optic disc drusen, small hypermetropic discs, titled myopic discs and vitreous traction can all be mistaken for papilloedema [7].
Testing visual function is essential as not only is there no correlation between headache frequency and the degree of papilloedema [80], there is little correlation between papilloedema grade and LP OP. Visual function importantly guides management, particularly in the acute setting of diagnosis or in established IIH with an acute exacerbation of headache [81]. The minimum visual data set recommended is a visual acuity, pupil examination, formal visual field assessment and dilated fundal examination [2, 82]. Where possible ocular imaging is helpful at baseline to document papilloedema and is essential for longitudinal follow-up either by photography or optical coherence tomography (OCT) (Fig. 1). Indeed certain OCT measures show the ability to help distinguish between papilloedema and pseudopapilloedema [83] and other investigators have found associations and correlations with ICP [84]. As with any device, care in interpretation is important due to proprietary software errors in moderate to severe papilloedema (Fig. 2) [85].

Visual fields are typically the first part of the visual function affected by ICP with peripheral constriction, an enlargement of the blind spot and or an inferior nasal step or partial arcuate defect [86, 87]. For the general neurologist, interpretation of the visual fields is essential as in IIH cognitive factors including subject attention, motivation, fatigue, and response bias can influence the results. For example, in the IIH TT, one-fifth of the visual fields had to be repeated due to poor reliability [88]. Understanding of the type of visual field loss and how to interpret the plots presented, reliability indices and global parameters is helpful [82].

\section{Emergency management}

Less than $10 \%$ of those with IIH [3] present with rapidly progressive loss of visual function (termed fulminant IIH) and in whom an acute reduction in ICP is required to preserve vision, and so in these cases, surgical intervention is necessary [2, 82]. Established options include CSF diversion with the commonest surgeries being a ventriculoperitoneal (VP) shunt or lumboperitoneal (LP) shunt, or optic nerve sheath fenestration (ONSF). CSF diversion and shunt revision surgeries are the commonest intervention for fulminant IIH [3], with a third of patients requiring multiple revision surgeries [89]. Ventriculoperitoneal shunts are currently preferred [2, 82], due to the reported lower revision rates compared to lumboperitoneal shunts (1.8 versus 4.3 revisions per patient, respectively [90]).

More recently cerebral venous sinus stenting (CVSS) has been popularized through various case series and may be of particular benefit in these urgent cases [91, 92]. Saber et al. concluded that in patients with refractory IIH and venous 


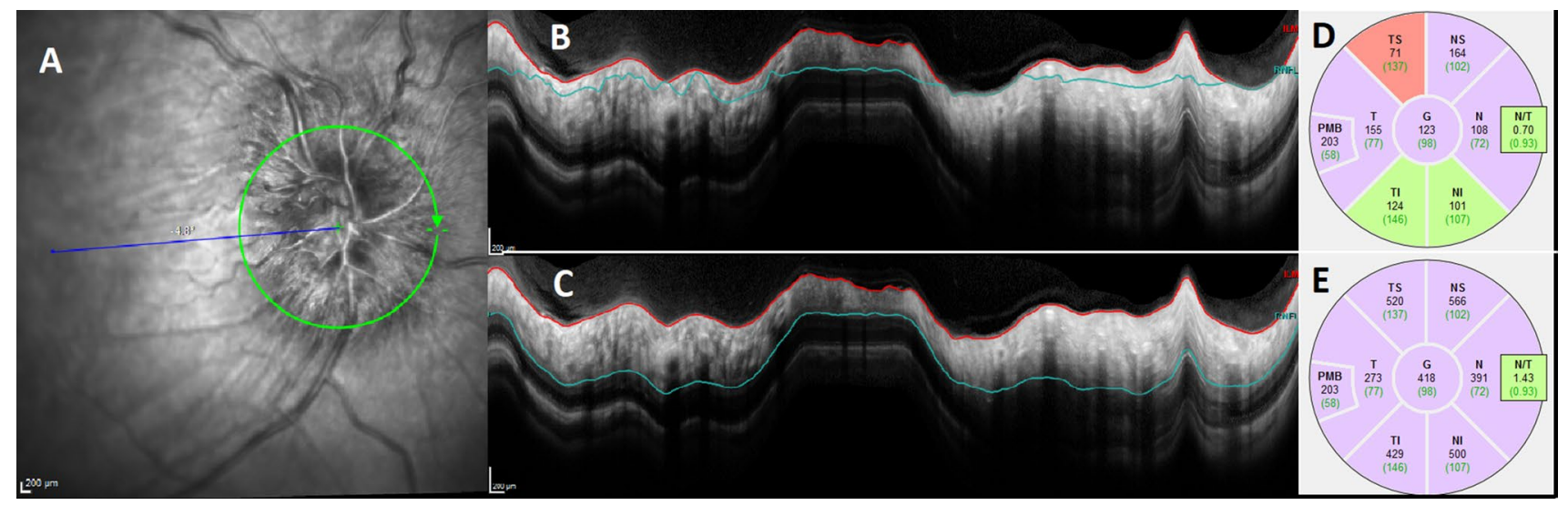

Fig. 2 Segmentation error is common in higher grades of papilloedema. a The infrared image of the right eye with a Frisén grade 3 disc swelling, as graded on biomicroscopy. b The blue line, segmenting the retinal nerve fibre layer (RNFL), has been automatically placed in the incorrect area. $\mathbf{c}$ the manual resegmentation of the

sinus stenosis with elevated pressure gradients, venous sinus stenting was associated with a reduction in pressure gradient and ICP, improvement in signs and symptoms of IIH and acceptable stent survival rates [92]. The rate of serious complications (including intracranial haemorrhage, venous sinus thrombosis and ultimately death) has been reported as less than $2 \%$ in a number of systematic reviews [93], and around 5\% in a large case series [94].

There is a lack of randomised controlled trials (RCT) evaluating the effectiveness of all the surgical interventions for IIH and the effectiveness of each remains uncertain. Comparing the three interventions, Satti et al. reported that the overall rate of serious complication following venous sinus stenting $(2.9 \%)$ was higher than following OSNF (1.5\%) but significantly lower than following CSF diversion $(7.6 \%)[95]$.

\section{Conclusion}

Basic science research has started to uncover the metabolic aetiology of IIH. There is a clear unmet need for biomarkers of disease activity and better tolerated treatments. Translating this knowledge will better serve our patients and health community, where IIH still carries a significant stigma and bias due to its association with obesity.

Funding AS is funded by a Sir Jules Thorn Award for Biomedical Science. OG is funded by a Brain Research UK PhD Studentship. GG is supported by a Wellcome Trust Senior Fellowship (104612/Z/14/Z).
RNFL. d The initial figures for the retinal nerve fibre layer values in each segment. e The resegmented values of the RNFL, and can be compared directly to d, highlighting the difference that might clearly change clinical management when longitudinally following a patient

\section{Compliance with ethical standards}

Conflicts of interest OG-consultancy work for Invex therapeutics (2020). SPM-Invex therapeutics advisory board (2019); Heidelberg engineering speaker fees (2019). BW-consultancy work for Invex therapeutics (2020). ZA-no conflicts. GL-no conflicts. AJSNovartis and Allergan Advisory board. Speaker fees Novartis. Invex therapeutics, company director with salary and stock options (2019, 2020).

Open Access This article is licensed under a Creative Commons Attribution 4.0 International License, which permits use, sharing, adaptation, distribution and reproduction in any medium or format, as long as you give appropriate credit to the original author(s) and the source, provide a link to the Creative Commons licence, and indicate if changes were made. The images or other third party material in this article are included in the article's Creative Commons licence, unless indicated otherwise in a credit line to the material. If material is not included in the article's Creative Commons licence and your intended use is not permitted by statutory regulation or exceeds the permitted use, you will need to obtain permission directly from the copyright holder. To view a copy of this licence, visit http://creativecommons.org/licenses/by/4.0/.

\section{References}

1. Markey KA, Mollan SP, Jensen RH, Sinclair AJ (2016) Understanding idiopathic intracranial hypertension: mechanisms, management, and future directions. Lancet Neurol 15(1):78-91

2. Mollan SP, Davies B, Silver NC, Shaw S, Mallucci CL, Wakerley BR, Krishnan A, Chavda SV, Ramalingam S, Edwards J et al (2018) Idiopathic intracranial hypertension: consensus guidelines on management. J Neurol Neurosurg Psychiatry 89(10):1088-1100

3. Mollan SP, Aguiar M, Evison F, Frew E, Sinclair AJ (2018) The expanding burden of idiopathic intracranial hypertension. Eye (Lond) 33(3):478-485

4. McCluskey G, Doherty-Allan R, McCarron P, Loftus AM, McCarron LV, Mulholland D, McVerry F, McCarron MO (2018) 
Meta-analysis and systematic review of population-based epidemiological studies in idiopathic intracranial hypertension. Eur J Neurol 25(10):1218-1227

5. Wall M, Kupersmith MJ, Kieburtz KD, Corbett JJ, Feldon SE, Friedman DI, Katz DM, Keltner JL, Schron EB, McDermott MP et al (2014) The idiopathic intracranial hypertension treatment trial: clinical profile at baseline. JAMA Neurol 71(6):693-701

6. Mollan SP, Ali F, Hassan-Smith G, Botfield H, Friedman DI, Sinclair AJ (2016) Evolving evidence in adult idiopathic intracranial hypertension: pathophysiology and management. J Neurol Neurosurg Psychiatry 87(9):982-992

7. Mollan SP, Markey KA, Benzimra JD, Jacks A, Matthews TD, Burdon MA, Sinclair AJ (2014) A practical approach to, diagnosis, assessment and management of idiopathic intracranial hypertension. Pract Neurol 14(6):380-390

8. Mulla Y, Markey KA, Woolley RL, Patel S, Mollan SP, Sinclair AJ (2015) Headache determines quality of life in idiopathic intracranial hypertension. J Headache Pain 16:521-521

9. Mollan SP, Hoffmann J, Sinclair AJ (2019) Advances in the understanding of headache in idiopathic intracranial hypertension. Curr Opin Neurol 32(1):92-98

10. Mollan S, Hemmings K, Herd CP, Denton A, Williamson S, Sinclair AJ (2019) What are the research priorities for idiopathic intracranial hypertension? A priority setting partnership between patients and healthcare professionals. BMJ Open 9(3):e026573

11. Botfield HF, Uldall MS, Westgate CSJ, Mitchell JL, Hagen SM, Gonzalez AM, Hodson DJ, Jensen RH, Sinclair AJ (2017) A glucagon-like peptide-1 receptor agonist reduces intracranial pressure in a rat model of hydrocephalus. Sci Transl Med 9(404):eaan0972

12. Markey K, Mitchell J, Botfield H, Ottridge RS, Matthews T, Krishnan A, Woolley R, Westgate C, Yiangou A, Alimajstorovic $\mathrm{Z}$ et al (2020) 11 $\beta$-Hydroxysteroid dehydrogenase type 1 inhibition in idiopathic intracranial hypertension: a double-blind randomized controlled trial. Brain Commun 2(1):fcz050

13. Markey KA, Ottridge R, Mitchell JL, Rick C, Woolley R, Ives N, Nightingale P, Sinclair AJ (2017) Assessing the efficacy and safety of an 11beta-hydroxysteroid dehydrogenase type 1 inhibitor (AZD4017) in the idiopathic intracranial hypertension drug trial, IIH:DT: clinical methods and design for a phase II randomized controlled trial. JMIR Res Protoc 6(9):e181

14. IIH Pressure Clinical Trial ISTCRN (12678718). http://www. isrctn.com/ISRCTN12678718. Website last accessed 20 July 2020

15. Raoof N, Sharrack B, Pepper IM, Hickman SJ (2011) The incidence and prevalence of idiopathic intracranial hypertension in Sheffield, UK. Eur J Neurol 18(10):1266-1268

16. Radhakrishnan K, Ahlskog JE, Cross SA, Kurland LT, O'Fallon WM (1993) Idiopathic intracranial hypertension (pseudotumor cerebri): descriptive epidemiology in Rochester, Minn, 19761990. Arch Neurol 50(1):78-80

17. Durcan FJ, Corbett JJ, Wall M (1988) The incidence of pseudotumor cerebri: population studies in Iowa and Louisiana. Arch Neurol 45(8):875-877

18. Craig JJ, Mulholland DA, Gibson JM (2001) Idiopathic intracranial hypertension; incidence, presenting features and outcome in Northern Ireland (1991-1995). Ulst Med J 70(1):31-35

19. Kesler A, Stolovic N, Bluednikov Y, Shohat T (2014) The incidence of idiopathic intracranial hypertension in Israel from 2005 to 2007: results of a nationwide survey. Eur J Neurol 21(8):1055-1059

20. Adderley NJ, Subramanian A, Nirantharakumar K, Yiangou A, Gokhale KM, Mollan SP, Sinclair AJ (2019) Association between idiopathic intracranial hypertension and risk of cardiovascular diseases in women in the United Kingdom. JAMA Neurol 76(9):1088-1098
21. Friesner D, Rosenman R, Lobb BM, Tanne E (2011) Idiopathic intracranial hypertension in the USA: the role of obesity in establishing prevalence and healthcare costs. Obes Rev 12(5):e372-e380

22. Matthews YY, Dean F, Lim MJ, McLachlan K, Rigby AS, Solanki GA, White CP, Whitehouse WP, Kennedy CR (2017) Pseudotumor cerebri syndrome in childhood: incidence, clinical profile and risk factors in a national prospective populationbased cohort study. Arch Dis Child 102(8):715-721

23. Bruce BB, Kedar S, Van Stavern GP, Monaghan D, Acierno MD, Braswell RA, Preechawat P, Corbett JJ, Newman NJ, Biousse V (2009) Idiopathic intracranial hypertension in men. Neurology 72(4):304-309

24. Lun MP, Monuki ES, Lehtinen MK (2015) Development and functions of the choroid plexus-cerebrospinal fluid system. Nat Rev Neurosci 16(8):445-457

25. Fisone G, Snyder GL, Fryckstedt J, Caplan MJ, Aperia A, Greengard P (1995) $\mathrm{Na}^{+}, \mathrm{K}^{+}$-ATPase in the choroid plexus. Regulation by serotonin/protein kinase $\mathrm{C}$ pathway. J Biol Chem 270(6):2427-2430

26. Bothwell SW, Janigro D, Patabendige A (2019) Cerebrospinal fluid dynamics and intracranial pressure elevation in neurological diseases. Fluids Barriers CNS 16(1):9-9

27. Campbell JE, Drucker DJ (2013) Pharmacology, physiology, and mechanisms of incretin hormone action. Cell Metab 17(6):819-837

28. Flint A, Raben A, Astrup A, Holst JJ (1998) Glucagon-like peptide 1 promotes satiety and suppresses energy intake in humans. J Clin Investig 101(3):515-520

29. Carraro-Lacroix LR, Malnic G, Girardi AC (2009) Regulation of $\mathrm{Na}^{+} / \mathrm{H}^{+}$exchanger NHE3 by glucagon-like peptide 1 receptor agonist exendin- 4 in renal proximal tubule cells. Am J Physiol Ren Physiol 297(6):F1647-F1655

30. Avisar I, Gaton DD, Dania H, Stiebel-Kalish H (2012) The prevalence of polycystic ovary syndrome in women with idiopathic intracranial hypertension. Scientifica (Cairo) 2012:708042

31. Klein A, Stern N, Osher E, Kliper E, Kesler A (2013) Hyperandrogenism is associated with earlier age of onset of idiopathic intracranial hypertension in women. Curr Eye Res 38(9):972-976

32. Hornby C, Mollan SP, Mitchell J, Markey KA, Yangou A, Wright BLC, O'Reilly MW, Sinclair AJ (2017) What do transgender patients teach us about idiopathic intracranial hypertension? Neuro-Ophthalmology 41(6):326-329

33. O'Reilly MW, Westgate CS, Hornby C, Botfield H, Taylor AE, Markey K, Mitchell JL, Scotton WJ, Mollan SP, Yiangou A et al (2019) A unique androgen excess signature in idiopathic intracranial hypertension is linked to cerebrospinal fluid dynamics. JCI Insight 4(6):e125348

34. Sinclair AJ, Onyimba CU, Khosla P, Vijapurapu N, Tomlinson JW, Burdon MA, Stewart PM, Murray PI, Walker EA, Rauz S (2007) Corticosteroids, 11 beta-hydroxysteroid dehydrogenase isozymes and the rabbit choroid plexus. J Neuroendocrinol 19(8):614-620

35. Sinclair AJ, Walker EA, Burdon MA, van Beek AP, Kema IP, Hughes BA, Murray PI, Nightingale PG, Stewart PM, Rauz S et al (2010) Cerebrospinal fluid corticosteroid levels and cortisol metabolism in patients with idiopathic intracranial hypertension: a link between 11 beta-HSD1 and intracranial pressure regulation? J Clin Endocrinol Metab 95(12):5348-5356

36. Stimson RH, Walker BR (2013) The role and regulation of 11 betahydroxysteroid dehydrogenase type 1 in obesity and the metabolic syndrome. Horm Mol Biol Clin Investig 15(2):37-48

37. Sandeep TC, Andrew R, Homer NZ, Andrews RC, Smith K, Walker BR (2005) Increased in vivo regeneration of cortisol in adipose tissue in human obesity and effects of the 11beta-hydroxysteroid dehydrogenase type 1 inhibitor carbenoxolone. Diabetes 54(3):872-879 
38. Masuzaki H, Paterson J, Shinyama H, Morton NM, Mullins JJ, Seckl JR, Flier JS (2001) A transgenic model of visceral obesity and the metabolic syndrome. Science 294(5549):2166-2170

39. Westgate C, Markey K, Ludwig C, Singhal R, Lavery G, Sinclair A (2018) Subcutaneous adipose tissue from patients with idiopathic intracranial hypertension exhibits metabolically distinctive characteristics. In: Society for endocrinology BES 2018. Glasgow, United Kingdom

40. Boyle CD (2008) Recent advances in the discovery of 11 betaHSD1 inhibitors. Curr Opin Drug Discov Dev 11(4):495-511

41. Hornby C, Mollan SP, Botfield H, O'Reilly MW, Sinclair AJ (2018) Metabolic concepts in idiopathic intracranial hypertension and their potential for therapeutic intervention. J Neuro-ophthalmol 38(4):522-530

42. Dhungana S, Sharrack B, Woodroofe N (2009) Cytokines and chemokines in idiopathic intracranial hypertension. Headache 49(2):282-285

43. Zanello SB, Tadigotla V, Hurley J, Skog J, Stevens B, Calvillo E, Bershad E (2018) Inflammatory gene expression signatures in idiopathic intracranial hypertension: possible implications in microgravity-induced ICP elevation. npj Microgravity 4(1): 1

44. Edwards LJ, Sharrack B, Ismail A, Tench CR, Gran B, Dhungana S, Brettschneider J, Tumani H, Constantinescu CS (2013) Increased levels of interleukins 2 and 17 in the cerebrospinal fluid of patients with idiopathic intracranial hypertension. Am J Clin Exp Immunol 2(3):234-244

45. Alimajstorovic Z, Pascual-Baixauli E, Hawkes CA, Sharrack B, Loughlin AJ, Romero IA, Preston JE (2020) Cerebrospinal fluid dynamics modulation by diet and cytokines in rats. Fluids Barriers CNS 17(1):10

46. Sinclair AJ, Burdon MA, Nightingale PG, Ball AK, Good P, Matthews TD, Jacks A, Lawden M, Clarke CE, Stewart PM et al (2010) Low energy diet and intracranial pressure in women with idiopathic intracranial hypertension: prospective cohort study. BMJ 341:c2701

47. Manfield JH, Yu KK, Efthimiou E, Darzi A, Athanasiou T, Ashrafian H (2017) Bariatric surgery or non-surgical weight loss for idiopathic intracranial hypertension? A systematic review and comparison of meta-analyses. Obes Surg 27(2):513-521

48. Ottridge R, Mollan SP, Botfield H, Frew E, Ives NJ, Matthews T, Mitchell J, Rick C, Singhal R, Woolley R et al (2017) Randomised controlled trial of bariatric surgery versus a community weight loss programme for the sustained treatment of idiopathic intracranial hypertension: the Idiopathic Intracranial Hypertension Weight Trial (IIH:WT) protocol. BMJ Open 7(9):e017426

49. Wall M, McDermott MP, Kieburtz KD, Corbett JJ, Feldon SE, Friedman DI, Katz DM, Keltner JL, Schron EB, Kupersmith MJ (2014) Effect of acetazolamide on visual function in patients with idiopathic intracranial hypertension and mild visual loss: the idiopathic intracranial hypertension treatment trial. JAMA 311(16):1641-1651

50. Uldall M, Botfield H, Jansen-Olesen I, Sinclair A, Jensen R (2017) Acetazolamide lowers intracranial pressure and modulates the cerebrospinal fluid secretion pathway in healthy rats. Neurosci Lett 645:33-39

51. Smith SV, Friedman DI (2017) The idiopathic intracranial hypertension treatment trial: a review of the outcomes. Headache 57(8):1303-1310

52. Ball AK, Howman A, Wheatley K, Burdon MA, Matthews T, Jacks AS, Lawden M, Sivaguru A, Furmston A, Howell S et al (2011) A randomised controlled trial of treatment for idiopathic intracranial hypertension. J Neurol 258(5):874-881

53. Piper RJ, Kalyvas AV, Young AM, Hughes MA, Jamjoom AA, Fouyas IP (2015) Interventions for idiopathic intracranial hypertension. Cochrane Database Syst Rev (8):Cd003434
54. Scotton WJ, Botfield HF, Westgate CS, Mitchell JL, Yiangou A, Uldall MS, Jensen RH, Sinclair AJ (2019) Topiramate is more effective than acetazolamide at lowering intracranial pressure. Cephalalgia 39(2):209-218

55. Alore PL, Jay WM, Macken MP (2006) Topiramate, pseudotumor cerebri, weight-loss and glaucoma: an ophthalmologic perspective. Semin Ophthalmol 21(1):15-17

56. Celebisoy N, Gokcay F, Sirin H, Akyurekli O (2007) Treatment of idiopathic intracranial hypertension: topiramate vs acetazolamide, an open-label study. Acta Neurol Scand 116(5):322-327

57. Finsterer J, Foldy D, Fertl E (2006) Topiramate resolves headache from pseudotumor cerebri. J Pain Symptom Manag 32(5):401-402

58. Mollan SP, Spitzer D, Nicholl DJ (2018) Raised intracranial pressure in those presenting with headache. BMJ 363:k3252

59. Headache Classification Committee of the International Headache Society (IHS) (2018) The international classification of headache disorders, 3rd edition. Cephalalgia 38(1):1-211

60. Friedman DI, Quiros PA, Subramanian PS, Mejico LJ, Gao S, McDermott M, Wall M (2017) Headache in idiopathic intracranial hypertension: findings from the idiopathic intracranial hypertension treatment trial. Headache 57(8):1195-1205

61. Friedman DI (2019) Headaches in idiopathic intracranial hypertension. J Neuro-ophthalmol 39(1):138

62. Wakerley BR (2019) Medication-overuse headache. Pract Neurol 19(5):399-403

63. Fridley J, Foroozan R, Sherman V, Brandt ML, Yoshor D (2011) Bariatric surgery for the treatment of idiopathic intracranial hypertension. J Neurosurg 114(1):34-39

64. Duits FH, Martinez-Lage P, Paquet C, Engelborghs S, Lleo A, Hausner L, Molinuevo JL, Stomrud E, Farotti L, Ramakers I et al (2016) Performance and complications of lumbar puncture in memory clinics: results of the multicenter lumbar puncture feasibility study. Alzheimers Dement 12(2):154-163

65. Yiangou A, Mitchell J, Markey KA, Scotton W, Nightingale P, Botfield H, Ottridge R, Mollan SP, Sinclair AJ (2019) Therapeutic lumbar puncture for headache in idiopathic intracranial hypertension: minimal gain, is it worth the pain? Cephalalgia 39(2):245-253

66. Penfield W, McNaughton F (1940) Dural headache and innervation of the dura mater. Arch Neurol Psychiatry 44(1):43-75

67. Uddman R, Edvinsson L, Ekman R, Kingman T, McCulloch J (1985) Innervation of the feline cerebral vasculature by nerve fibers containing calcitonin gene-related peptide: trigeminal origin and co-existence with substance P. Neurosci Lett 62(1):131-136

68. Iyengar S, Johnson KW, Ossipov MH, Aurora SK (2019) CGRP and the trigeminal system in migraine. Headache 59(5):659-681

69. Moulton EA, Burstein R, Tully S, Hargreaves R, Becerra L, Borsook D (2008) Interictal dysfunction of a brainstem descending modulatory center in migraine patients. PLoS ONE 3(11):e3799-e3799

70. Bigal ME, Edvinsson L, Rapoport AM, Lipton RB, Spierings EL, Diener HC, Burstein R, Loupe PS, Ma Y, Yang R et al (2015) Safety, tolerability, and efficacy of TEV-48125 for preventive treatment of chronic migraine: a multicentre, randomised, double-blind, placebo-controlled, phase $2 \mathrm{~b}$ study. Lancet Neurol 14(11):1091-1100

71. Dodick DW, Goadsby PJ, Silberstein SD, Lipton RB, Olesen J, Ashina M, Wilks K, Kudrow D, Kroll R, Kohrman B et al (2014) Safety and efficacy of ALD403, an antibody to calcitonin generelated peptide, for the prevention of frequent episodic migraine: a randomised, double-blind, placebo-controlled, exploratory phase 2 trial. Lancet Neurol 13(11):1100-1107

72. Dodick DW, Goadsby PJ, Spierings EL, Scherer JC, Sweeney SP, Grayzel DS (2014) Safety and efficacy of LY2951742, a monoclonal antibody to calcitonin gene-related peptide, for the prevention 
of migraine: a phase 2, randomised, double-blind, placebo-controlled study. Lancet Neurol 13(9):885-892

73. Shi L, Lehto SG, Zhu DX, Sun H, Zhang J, Smith BP, Immke DC, Wild KD, Xu C (2016) Pharmacologic characterization of AMG 334, a potent and selective human monoclonal antibody against the calcitonin gene-related peptide receptor. J Pharmacol Exp Ther 356(1):223-231

74. Tepper S, Ashina M, Reuter U, Brandes JL, Dolezil D, Silberstein S, Winner P, Leonardi D, Mikol D, Lenz R (2017) Safety and efficacy of erenumab for preventive treatment of chronic migraine: a randomised, double-blind, placebo-controlled phase 2 trial. Lancet Neurol 16(6):425-434

75. Yuan H, Spare NM, Silberstein SD (2019) Targeting CGRP for the prevention of migraine and cluster headache: a narrative review. Headache 59(Suppl 2):20-32

76. Moye LS, Pradhan AA (2017) From blast to bench: a translational mini-review of posttraumatic headache. J Neurosci Res 95(6):1347-1354

77. Navratilova E, Rau J, Oyarzo J, Tien J, Mackenzie K, Stratton J, Remeniuk B, Schwedt T, Anderson T, Dodick D, Porreca F (2019) CGRP-dependent and independent mechanisms of acute and persistent post-traumatic headache following mild traumatic brain injury in mice. Cephalalgia 39(14):1762-1775

78. Friedman DI, Liu GT, Digre KB (2013) Revised diagnostic criteria for the pseudotumor cerebri syndrome in adults and children. Neurology 81(13):1159-1165

79. Fisayo A, Bruce BB, Newman NJ, Biousse V (2016) Overdiagnosis of idiopathic intracranial hypertension. Neurology 86(4):341-350

80. Digre KB, Nakamoto BK, Warner JE, Langeberg WJ, Baggaley SK, Katz BJ (2009) A comparison of idiopathic intracranial hypertension with and without papilledema. Headache 49(2):185-193

81. Mollan SP, Hornby C, Mitchell J, Sinclair AJ (2018) Evaluation and management of adult idiopathic intracranial hypertension. Pract Neurol 18(6):485-488

82. Hoffmann J, Mollan SP, Paemeleire K, Lampl C, Jensen RH, Sinclair AJ (2018) European headache federation guideline on idiopathic intracranial hypertension. J Headache Pain 19(1):93

83. Fard MA, Fakhree S, Abdi P, Hassanpoor N, Subramanian PS (2014) Quantification of peripapillary total retinal volume in pseudopapilledema and mild papilledema using spectral-domain optical coherence tomography. Am J Ophthalmol 158(1):136-143

84. Skau M, Yri H, Sander B, Gerds TA, Milea D, Jensen R (2013) Diagnostic value of optical coherence tomography for intracranial pressure in idiopathic intracranial hypertension. Graefes Arch Clin Exp Ophthalmol 251(2):567-574
85. Aojula A, Mollan SP, Horsburgh J, Yiangou A, Markey KA, Mitchell JL, Scotton WJ, Keane PA, Sinclair AJ (2018) Segmentation error in spectral domain optical coherence tomography measures of the retinal nerve fibre layer thickness in idiopathic intracranial hypertension. BMC Ophthalmol 17(1):257

86. Pollak L, Zohar E, Glovinsky Y, Huna-Baron R (2013) Reevaluation of presentation and course of idiopathic intracranial hypertension-a large cohort comprehensive study. Acta Neurol Scand 127(6):406-412

87. Wong SH, Plant GT (2015) How to interpret visual fields. Pract Neurol 15(5):374

88. Cello KE, Keltner JL, Johnson CA, Wall M (2016) Factors affecting visual field outcomes in the idiopathic intracranial hypertension treatment trial. J Neuroophthalmol 36(1):6-12

89. Sinclair AJ, Kuruvath S, Sen D, Nightingale PG, Burdon MA, Flint G (2011) Is cerebrospinal fluid shunting in idiopathic intracranial hypertension worthwhile? A 10-year review. Cephalalgia 31(16):1627-1633

90. Kalyvas AV, Hughes M, Koutsarnakis C, Moris D, Liakos F, Sakas DE, Stranjalis G, Fouyas I (2017) Efficacy, complications and cost of surgical interventions for idiopathic intracranial hypertension: a systematic review of the literature. Acta Neurochir (Wien) 159(1):33-49

91. Gurney SP, Ramalingam S, Thomas A, Sinclair AJ, Mollan SP (2020) Exploring the current management idiopathic intracranial hypertension, and understanding the role of dural venous sinus stenting. Eye Brain 12:1-13

92. Saber H, Lewis W, Sadeghi M, Rajah G, Narayanan S (2018) Stent survival and stent-adjacent stenosis rates following venous sinus stenting for idiopathic intracranial hypertension: a systematic review and meta-analysis. Interv Neurol 7(6):490-500

93. Nicholson P, Brinjikji W, Radovanovic I, Hilditch CA, Tsang ACO, Krings T, Mendes Pereira V, Lenck S (2019) Venous sinus stenting for idiopathic intracranial hypertension: a systematic review and meta-analysis. J Neurointerv Surg 11(4):380-385

94. Asif H, Craven CL, Siddiqui AH, Shah SN, Matloob SA, Thorne L, Robertson F, Watkins LD, Toma AK (2018) Idiopathic intracranial hypertension: 120-day clinical, radiological, and manometric outcomes after stent insertion into the dural venous sinus. J Neurosurg 129(3):723-731

95. Satti SR, Leishangthem L, Chaudry MI (2015) Meta-analysis of CSF diversion procedures and dural venous sinus stenting in the setting of medically refractory idiopathic intracranial hypertension. AJNR Am J Neuroradiol 36(10):1899-1904 